\title{
Identification of Lactic Acid Bacteria from Luwak (Paradoxurus hermaphroditus) Gastrointestinal Tract
}

\author{
Fitri Fitri', Abu Bakar Tawali ${ }^{2}$, Amran Laga ${ }^{2}$ and Zaraswati Dwyana ${ }^{3}$ \\ ${ }^{1}$ Agricultural Science Study Program, Postgraduate School of Hasanuddin University, Perintis Kemerdekaan Street Km. 10 \\ Tamalanrea, Makassar, 90245, Indonesia \\ ${ }^{2}$ Food Science and Technology Study Program, Department of Agricultural Technology, Faculty of Agriculture, Hasanuddin \\ University, Perintis Kemerdekaan Street Km. 10 Tamalanrea, Makassar, 90245, Indonesia \\ ${ }^{3}$ Department of Biology, Faculty of Math and Science, Hasanuddin University, Perintis Kemerdekaan Street Km. 10 \\ Tamalanrea, Makassar, 90245, Indonesia \\ *For correspondence: abubakar_tawali@unhas.ac.id \\ Received 08 May 2021; Accepted 1 November 2021; Published 15 December 2021
}

\begin{abstract}
Luwak is a mammal that is widely cultivated to produce luwak coffee. Luwak coffee is a rare and one of the world's most expensive coffees from Indonesia. Numerous enzymes and microorganisms, many of which are lactic acid bacteria, contribute to the production of the coffee aroma. This research aims to identify lactic acid bacteria from luwak digestion accurately down to the species level. The parameters tested in this study were Gram staining, bacterial resistance to acid, bacterial resistance to bile salts, and genotypic identification of isolates using the 16S rRNA gene sequencing method. The results found that US1, FS3, FS4 and FS6 were identified as Leuconostoc pseudomesenteroides, US2 and US3 were identified as Lactobacillus plantarum, FS2 was identified as Weissella cibaria and FS5 was identified as Staphylococcus haemolyticus. All of these isolates were included in Gram-positive based on the results of Gram staining. However, among the 8 isolates obtained, one isolate, namely FS5 ( $S$. haemolyticus), was not a lactic acid bacterium, but a pathogenic bacterium. This information can be used for the development of luwak origin bacteria for in vitro coffee fermentation purposes. (C) 2021 Friends Science Publishers
\end{abstract}

Keywords: Lactic acid bacteria, Luwak, Gastrointestinal tract, 16S rRNA

\section{Introduction}

Asian palm civet (Paradoxurus hermaphroditus), known as the "luwak" in Indonesia, is a mammal belonging to the Viverridae family. This animal has a long tail, short and small legs (Rahardjo 2012; Maha et al. 2018) and has glands that can release a pandan aroma (Rahardjo 2012). Luwak is a nocturnal animal that is active at night searching for food (Rahardjo 2012; Nijman et al. 2014; Winaya et al. 2020). This species is an omnivore that generally eats fruits such as banana, papaya, or coffee but sometimes consumes insects, small vertebrates, or reptiles (Rahardjo 2012; Fitri et al. 2019; Winaya et al. 2020). Basically, luwak is a wild animal that lives in the forest. However, in Indonesia, these animals are widely cultivated to produce luwak coffee (Schmidt-Burbach et al. 2014; Winaya et al. 2020).

Luwak coffee is a rare and one of the world's most expensive coffees from Indonesia. The fermentation processes in the gastrointestinal tract of luwak give a unique aroma and an excellent taste to the coffee, which is preferred by coffee consumers worldwide (Fitri et al. 2019;
Winaya et al. 2020). Various enzymes and microorganisms, which are lactic acid bacteria, play a role in the coffee aroma formation (Fitri et al. 2019).

The high consumer interest in luwak coffee has increased the curiosity of researchers to explore the bacteria found in the digestive tract of luwak. Efforts to isolate and identify these bacteria are starting to be carried out. However, the identification carried out was only limited to phenotypic identification (Fauzi 2008).

Identification of lactic acid bacteria can be carried out based on the phenotypic and genotypic properties. Phenotypic identification is based on the colony morphological observations, microscopic observations (Gram stain), physiological, metabolic (biochemical), or chemotaxonomic tests. Meanwhile, genotypic identification is carried out using molecular methods, such as the Polymerase Chain Reactions (Ammor et al. 2005; Donelli et al. 2013). The phenotypic identification method has many weaknesses, including identification that takes a long time, and the level of accuracy is low due to its subjective interpretation (Donelli et al. 2013). 
This study aims to accurately classify lactic acid bacteria isolated from luwak digestion down to the species level. The 16S rRNA gene sequencing method was used to identify the bacteria in this study.

\section{Materials and Methods}

\section{Materials}

Lactic acid bacteria samples used were isolated from luwak digestion (colon and feces) from previous research, which were coded with US1, US2, US3, FS2, FS3, FS4, FS5 and FS6 (Tawali et al. 2019).

\section{Gram staining}

Gram staining was done by dripped a solution of crystal violet dye, iodine, $95 \%$ ethanol, and safranin sequentially on each sample.

\section{Acidity resistance test}

The resistance of microbial isolates to gastric acid in the digestive tract with low $\mathrm{pH}$ was carried out by inoculated each sample into MRS Broth $+\mathrm{HCl} 0.1 \mathrm{~N}$ (set at $\mathrm{pH} 3$ ) and incubated for $2 \times 24 \mathrm{~h}$ at $37^{\circ} \mathrm{C}$. A positive result was indicated by the occurrence of bacterial growth in a medium that has low acidity. The result was negative if there was no microbial growth in the medium.

\section{Bile salt resistance test}

MRS Broth was supplemented with 5\% synthetic bile salt (ox bile). Each sample was inoculated into MRSB-salt medium and incubated for $2 \times 24 \mathrm{~h}$ at $37^{\circ} \mathrm{C}$. Positive results were demonstrated by the presence of sediment at the tube's bottom and an improvement in the media's clarity relative to before incubation.

\section{DNA extraction}

Genomic DNA extraction was performed according to the protocol included in the TIANamp Genomic DNA Kit.

\section{DNA amplification using PCR}

This procedure was performed on extracted DNA isolates. To amplify the 16S rRNA sequence, primers 63f (5'CAGGCCTAACACATGCAAGTC-3') and 1387r (5'GGGCGGTGTGTACAAGGC-3') were used. The PCR master mix composition used was as follows: GoTaq MasterMix $16 \mu \mathrm{L}, 2 \mu \mathrm{L}$ forward primer, $2 \mu \mathrm{L}$ reverse primer, $4 \mu \mathrm{L} \mathrm{H}_{2} \mathrm{O}$ and $2 \mu \mathrm{L}$ DNA gene. The PCR machine used the following conditions: 5-min pre-denaturation at $95^{\circ} \mathrm{C}, 1-$ min denaturation at $95^{\circ} \mathrm{C}, 1-$ min annealing at $57^{\circ} \mathrm{C}$, 1 -min extension at $72^{\circ} \mathrm{C}, 10$-min post-extension at $72^{\circ} \mathrm{C}$, and kept at $4^{\circ} \mathrm{C}$ until 30 cycles were completed.

\section{Visualization of PCR results by electrophoresis}

1.5\% agarose gel was prepared in Erlenmeyer by dissolving $1.5 \mathrm{~g}$ of agarose powder in $100 \mathrm{~mL}$ of TAE Buffer, heated for 2 min until homogeneous, and then $8 \mu \mathrm{L}$ of Ethidium Bromide was added. Following that, the gel liquid was cooled to room temperature. After allowing the gel liquid to cool slightly, it was poured into a gel electrophoresis mold using a gel comb with a comb count of 24 wells. $5 \mu \mathrm{L}$ of each amplification product was put into a $1.5 \%$ agarose gel well submerged in a tank containing TAE buffer. Additionally, $50 \mathrm{~min}$ of electrophoresis at a constant voltage of 100 volts was performed. After $50 \mathrm{~min}$ the electrophoresis was terminated and the gel was extracted for UV light observation.

\section{DNA sequencing}

PCR products from samples that showed positive electrophoresis results were continued to the DNA sequencing. DNA samples were carried out by 1st Base through PT Genetika Indonesia. The DNA sequencing process was carried out using the Sanger dideoxy method. The sequencing results were analyzed by performing a BLAST search against the NCBI database at www.ncbi.nlm.nih.gov using the nucleotide sequences from the 16S rRNA gene sequencing results.

\section{Results}

\section{Morphology characterization of isolates}

Gram staining results performed on isolates can be used to determine the morphological characteristics of bacteria in their shape and Gram characteristics. The results of Gram staining of luwak digestive isolates can be seen in Table 1 and Fig. 1. Based on Table 1, it can be seen that three isolates obtained from luwak gastrointestinal, namely US2, US3, and FS2, had bacilli form, while five isolates, namely US1, FS3, FS4, FS5, and FS6, had cocci form. All isolates obtained were purple under the microscope (Fig. 1).

\section{Resistance of isolates from acid and bile salt}

The results of the resistance assay of luwak digestive isolates to acidity and bile salts (Table 1) showed that only one isolate, namely FS5, was unable to grow on acid or high concentration of bile salt conditions. In contrast, the other seven isolates, namely US1, US2, US3, FS2, FS3, FS4 and FS6, were able to grow on these conditions.

\section{Molecular identification of isolates from luwak gastrointestinal}

Molecular identification of isolates in this study was carried out using the $16 \mathrm{~S}$ rRNA gene sequence technique. 
Table 1: Resistance to $\mathrm{pH}$, bile salt and morphological observation results of luwak digestive lactic acid bacteria

\begin{tabular}{lllll}
\hline Isolates & \multicolumn{2}{c}{ Cell Morphology } & $\mathrm{pH} 3$ Resistance Bile Salt Resistance \\
\cline { 2 - 5 } & Shape & Gram & & +++ \\
\hline US1 & Cocci & Positive & +++ & +++ \\
US2 & Bacilli & Positive & +++ & +++ \\
US3 & Bacilli & Positive & +++ & ++ \\
FS2 & Bacilli & Positive & ++ & ++ \\
FS3 & Cocci & Positive & ++ & ++ \\
FS4 & Cocci & Positive & ++ & - \\
FS5 & Cocci & Positive & - & +++ \\
FS6 & Cocci & Positive & +++ & + (t)
\end{tabular}

Table 2: BLAST result of isolates from luwak gastrointestinal

\begin{tabular}{|c|c|c|c|c|}
\hline $\begin{array}{l}\text { Sample } \\
\text { Code }\end{array}$ & Homologous Species wi & $\begin{array}{l}\text { Query } \\
\text { Coverage }\end{array}$ & Identities & Accession \\
\hline US1 & $\begin{array}{l}\text { Leuconostoc pseudomesenteroides } \\
\text { strain MG5216 }\end{array}$ & $99 \%$ & $99,18 \%$ & MN368204.1 \\
\hline US2 & $\begin{array}{l}\text { Lactobacillus } \\
\text { CAU: } 227\end{array}$ & $99 \%$ & $99,67 \%$ & MF369879.1 \\
\hline US3 & $\begin{array}{l}\text { Lactobacillus plantarum strain } \\
\text { IMAU20905 }\end{array}$ & $99 \%$ & $98,71 \%$ & MK369825.1 \\
\hline FS2 & Weissella cibaria strain MG5327 & $98 \%$ & $99,15 \%$ & MN368586.1 \\
\hline FS3 & $\begin{array}{l}\text { Leuconostoc pseudomesenteroides } \\
\text { strain L12001 }\end{array}$ & $99 \%$ & $98,92 \%$ & KT952379.1 \\
\hline FS4 & $\begin{array}{l}\text { Leuconostoc pseudomesenteroides } \\
\text { strain: CF102 }\end{array}$ & $99 \%$ & $98,12 \%$ & AB854189.1 \\
\hline FS5 & $\begin{array}{l}\text { Staphylococcus haemolyticus strain } \\
\text { WS1-3 }\end{array}$ & $99 \%$ & $98,15 \%$ & MN448416.1 \\
\hline FS6 & $\begin{array}{l}\text { Leuconostoc pseudomesenteroides } \\
\text { strain: Ni1324 }\end{array}$ & $99 \%$ & $99,58 \%$ & AB598984.1 \\
\hline
\end{tabular}

16S rRNA gene sequences were performed after amplification of the DNA isolate by PCR. The visualization results in Fig. 2 show that all amplified isolates DNA had a size of $<1500 \mathrm{bp}$. The bands formed are single, thick, and bright bands. That condition showed the success of the PCR process carriesd out on isolate. Based on the analysis results using BLAST (Table 2 and Fig. 3), it was known that sample US2 and US3 were homolog with Lactobacillus plantarum, sample FS2 was homolog with Weisella cibaria, sample US1, FS3, FS4 and FS6 were homolog with Leuconostoc pseudomesenteroides, while FS5 was homolog with Staphylococcus haemolyticus.

\section{Discussion}

Bacteria, especially lactic acid bacteria, are commonly found and are closely related to all processes that take place in the digestive system of monogastric animals (Kraatz 2011). Various methods can be used to identify lactic acid bacteria. The identification method using the $16 \mathrm{~S}$ rRNA gene sequence is an identification method that is widely used to identify lactic acid bacteria more effectively. For example, to identify lactic acid bacteria from chicken digestion (Lee et al. 2008), native Aceh duck digestion, longan fruit (Hidayat et al. 2019) and buffalo milk (Melia et al. 2018).

Morphological observations and Gram staining are an initial screening to identify bacteria before the 16S rRNA

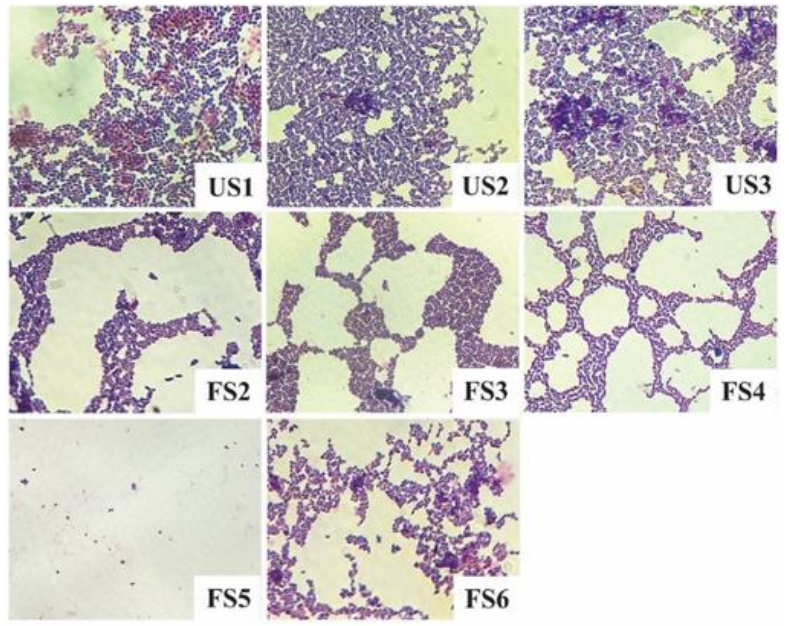

Fig. 1: Microscopic gram stain results of isolates from luwak gastrointestinal tract

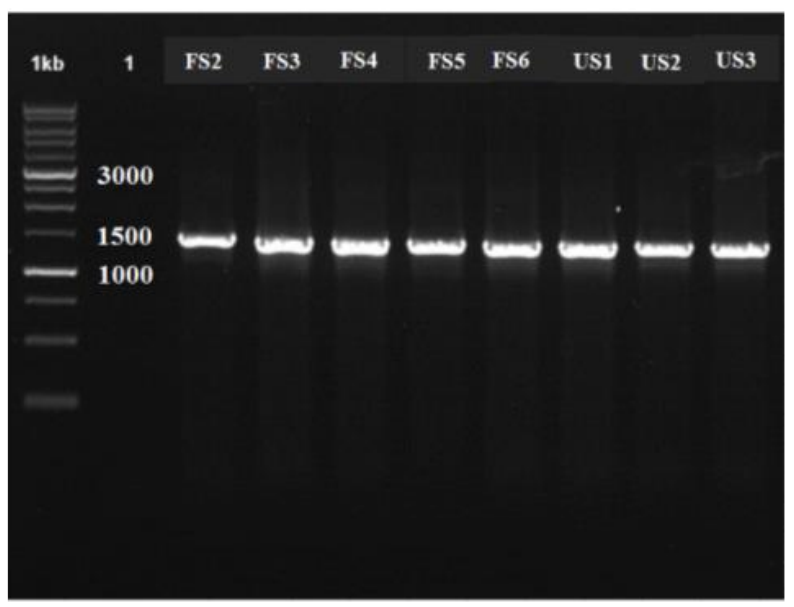

Fig. 2: Electrophoresis visualization of the amplification results of US1, US2, US3, FS2, FS3, FS4, FS5, dan FS6

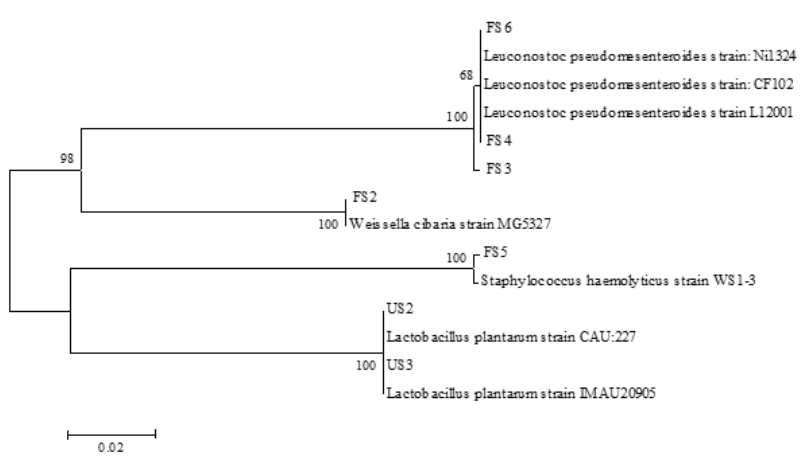

Fig. 3: Phylogenetic tree of $\mathrm{LAB}$ isolates from luwak gastrointestinal tract

gene sequence is performed. Gram staining is the most common method in the laboratory used to distinguish between Gram-positive and Gram-negative microorganisms (Becerra et al. 2016). Gram-positive bacteria have thick 
peptidoglycan walls so that they can maintain the color of crystal violet after decolorization, while Gram-negative bacteria have thin peptidoglycan walls, so they are unable to maintain color after washing with alcohol (Yazdankhah et al. 2001; Bailey 2020).

The purple color visualized under the microscope indicates that all of the isolates obtained were Gram-positive bacteria. Ismail et al. (2018) stated that lactic acid bacteria are included in the Gram-positive bacteria group. Grampositive bacteria show purple or blue color under a microscope as a result of Gram staining. Thus, based on Gram staining, the eight isolates obtained from luwak gastrointestinal tract could be categorized as lactic acid bacteria as an initial screening.

Isolates analyses based on their morphology are not sufficient to identify a bacterial species. Other tests are needed, for example, from the ability of bacteria to survive certain conditions. The resistance of bacteria to high acidity and bile salts could be used to test further to identify isolated bacteria. Lactic acid bacteria could be classified as probiotics (Zielińska and Kolohyn-Krajewska 2018). Probiotics are live microorganisms that can benefit the body, one of which is by improving the health of the human gut. Probiotics must survive in any conditions in the digestive tract to be able to carry out their functions (Jensen et al. 2012; Zielińska and Kolohyn-Krajewska 2018). Based on the result, it was shown that the eight isolates obtained from luwak digestion suspected that US1, US2, US3, FS2, FS3, FS4 and FS6 belong to the lactic acid bacteria group. At the same time, FS5 was not included in the lactic acid bacteria group.

Molecular identification is the most precise way used to identify lactic acid bacteria down to the species level. The isolates identification in this study was carried out using the 16S rRNA gene sequence technique. The first step to identify isolates by $16 \mathrm{~S}$ rRNA gene sequence was DNA extraction. DNA extraction aims to obtain DNA from an organism by separating it from the cell membrane and other cellular components (Gupta 2019). DNA extraction consists of three main stages: cell wall destruction (lysis), separation of DNA from other components, and DNA purification (Corkill and Rapley 2008). The DNA obtained will be used as a template in the amplification stage with PCR. The purified PCR products are then determined by sequencing the nucleotide sequence (Rinanda 2011).

DNA sequencing was done by Single Pass DNA Sequencing. Sequencing data were analyzed using nucleotide blasts at ncbi.nlm.niv.gov. Analysis of blast results provides information about organisms or bacteria that have homologous DNA sequences to the sample. The information can be used to identify the species of the isolates.

Based on the results of analysis using BLAST (Table 2 and Fig. 3), it was known that eight isolates obtained from luwak digestion were identified into four species, namely L. plantarum, L. pseudomesenteroides, Weissella cibaria, and $S$. haemolyticus with query coverage reaching 98-99\% and identities ranged from 98.12-99.67\%. Query coverage is the percentage of nucleotide length that is in line with the database contained in BLAST, while identity is the highest value of the percentage of identity or the match between query sequences and aligned database sequences (Newell et al. 2013). S. haemolyticus is a type of bacteria that is included in the coagulase-negative staphylococci group. These bacteria are normal bacteria that live on human skin and flora but can be pathogenic and cause urinary tract infections and other diseases (Suhartono et al. 2019). So that from eight isolates, only seven isolates from luwak digestion were identified as lactic acid bacteria, namely US1, US2, US3, FS2, FS3, FS4 and FS6.

\section{Conclusion}

Lactic acid and non-lactic acid bacteria can be found in the luwak gastrointestinal. The $16 \mathrm{~S}$ rRNA sequence method using universal primers $63 \mathrm{f}$ and $1387 \mathrm{r}$ not only can identify the lactic acid bacteria but also pathogenic bacteria such as S. haemolyticus. L. pseudomesenteroides, L. plantarum and $W$. cibaria are types of lactic acid bacteria found in the digestive tract of luwak. This information can be used for the development of civet origin bacteria for in vitro fermentation purposes.

\section{Acknowledgements}

This research was funded by Directorate of Research and Community Service, the Ministry of Research and Technology of Indonesia.

\section{Author Contributions}

FF, ABT, AL, and ZD designed the research flow. FF and $\mathrm{ZD}$ performed the research and wrote the manuscript. ABT and AL edited the manuscript.

\section{Conflicts of Interest}

The authors declare no conflict of interest.

\section{Data Availability}

Data presented in this study will be available on a reasonable request

\section{Ethics Approval}

Ethical approval is not applicable in this study.

\section{References}

Ammor S, C Rachman, S Chaillou, A Prẻvost, X Dousset, M Zagorec, E Dufour, I Chevallier (2005). Phenotypic and genotypic identification of lactic acid bacteria isolated from a small-scale facility producing traditional dry sausages. Food Microb 22:373-382 
Bailey R (2020). Gram positive vs. gram negative bacteria. Available at: https://www.thoughtco.com/gram-positive-gram-negative-bacteria4174239 (Accessed: 15 April 2020)

Becerra SC, DC Roy, CJ Sanchez, RJ Christy, DM Burmeister (2016). An optimized staining technique for the detection of gram positive and Gram negative bacteria within tissue. BMC Res Notes 9; Article 216

Corkill G, R Rapley (2008). The Manipulation of Nucleic Acids: Basic Tools and Techniques. In: Molecular Biomethods Handbook, $2^{\text {nd }}$ Edition, pp:3-16. Walker JM, R Rapley (Eds). Humana Press, Totowa, New Jersey, USA

Donelli G, C Vuotto, P Mastromarino (2013). Phenotyping and genotyping are both essential to identify and classify a probiotic microorganism. Microb Ecol Health Dis 24:1-9

Fauzi M (2008). Isolation and Characterization of Luwak Coffee Lactic acid Bacteria (civet coffe). Research Report. Faculty of Agricultural Technology. Jember University, Indonesia

Fitri, AB Tawali, A Laga (2019). Luwak coffee in vitro fermentation: Literature review, pp:1-6. In: IOP Conference Series: Earth and Environmental Science, Bristol, UK

Gupta N (2019). DNA extraction and polymerase chain reaction. J Cytol 36:116-117

Hidayat H, W Haryadi, S Matsjeh, TJ Raharjo (2019). Molecular identification $16 \mathrm{~S}$ rRNA gene of active proteolytic lactic acid bacteria (LAB) isolated from kelengkeng (Dimocarpus longan) fruit. Biodivers J Biol Divers 20:2222-2228

Ismail YS, C Yulvizar, B Mazhitov (2018). Characterization of lactic acid bacteria from local cow's milk kefir, pp:1-9. In: IOP Conference Series: Earth and Environmental Science, Bristol, UK

Jensen H, S Grimmer, K Naterstad, L Axelsson (2012). In vitro testing of commercial and potential probiotic lactic acid bacteria. Intl J Food Microbiol 153:216-222

Kraatz M (2011). Isolation of lactic acid-related bacteria from the pig mucosal proximal gastrointestinal tract, including Olsenella umbonata sp. Nov and Veillonella magna spp. nov. Master's Thesis. Faculty of Veterinary Medicine. Free University of Berlin, Germany

Lee CM, CC Sieo, N Abdullah, YW Ho (2008). Estimation of16S rRNAgene copy numberin several probiotic Lactobacillus strains isolated from the gastrointestinal tract of chicken. FEMS Microbiol Lett 287:136-141
Maha IT, IKM Adnyane, S Novelina (2018). Morphology of anal gland of common palm civet female (Paradoxurus hermaphroditus). J Kajian Vet 6:1-11 [In Indonesian]

Melia S, Y Yuherman, J Jaswandi, E Purwati (2018). Selection of buffalo milk lactic acid bacteria with probiotic potential. Asian J Pharm Clin Res 11:186-189

Newell PD, AD Fricker, CA Roco, P Chandrangsu, SM Merkel (2013). A small-group activity introducing the use and interpretation of BLAST. J Microbiol Biol Educ 14:238-243

Nijman V, D Spaan, EJ Rode-Margono, PD Roberts, NK Wirdateti, KAI Nekaris (2014). Trade in common palm civet Paradoxurus hermaphroditus in Javan and Balinese markets, Indonesia. Small Carniv Conserv 51:11-17

Rahardjo P (2012). Coffee: A Guide to Arabica and Robusta Coffee Cultivation and Processing. Penebar Swadaya, Jakarta [In Indonesian]

Rinanda T (2011). Sequencing analysis of 16s rRNA in microbiology. $J$ Kedokt Syiah Kuala 11:172-177

Schmidt-Burbach J, N D'Cruze, J Toole, K Mansell (2014). What is the true cost of the world's most expensive coffee? Oryx 48:169-171

Suhartono S, Z Hayati, M Mahmuda (2019). Distribution of Staphylococcus haemolyticus as the most dominant species among staphylococcal infections at the zainoel abidin hospital in aceh, Indonesia. Biodivers J Biol Divers 20:2076-2080

Tawali AB, A Laga, Fitri (2019). Isolation and identification of lactic acid bacteria from luwak gastrointestinal tract. Laporan Penelitian. Hasanuddin University, Makassar

Winaya A, Maftuchah, CM Nicolás, D Prasetyo (2020). Morphometric variations of Asian common palm civet (Paradoxurus hermaphroditus, pallas 1777) from Bali island, Indonesia as the basis of morphometrics diversity data. Biodivers $J$ Biol Divers 21:1027-1034

Yazdankhah SP, H Sørum, HJS Larsen, G Gogstad (2001). Rapid method for detection of gram-positive and -negative bacteria in milk from cows with moderate or severe clinical mastitis. J Clin Microbiol 39:3228-3233

Zielińska D, D Kolohyn-Krajewska (2018). Food-origin lactic acid bacteria may exhibit probiotic properties: Review. BioMed Res Intl 2018:1-15 